\title{
Water Rights: A key to sustainable development in Nepal
}

\author{
Madhav Narayan Shres tha \\ SNV Nepal West Portfolio (WaSH Consultant) \\ Email:mnshrestha@mail.com
}

\begin{abstract}
By addressing water, one will also address human development. People's lack of access to safe and secure water is not due to the quantity of water available on the earth but rather because the institutions set up to manage the issues are not up to the challenge. In Nepal Muluki Ain (Laws of Land) did not regulate water much in detail because water was not considered an important resource and a source of major revenue. Water rights are based on practices legitimized by law and they are related to political, economic and social relationship and to other rights such as land rights Muluki Ain (1854, 1952 and 1963),which regulates priority in acquiring water from water sources, and allocation of water. Acts promulgated between 1961 and 1992 reflect the growing importance of water resources in Nepalese political economy and not only empower the state to regulate water use, they also vested ownership of all water resources with the state. Although various Acts gave water rights to every citizen of Nepal, there are gender bias in executing power and rights to use water sources. Water scarcity problem can perhaps be due to geographical reality, climate change or to the excessive use of water resource in one sector and a resulting loss of raw water available for other uses. Issues such as good water governance, negotiation and collaboration for water sharing, awareness on values of water, management of water induced disasters etc needs specific attention.
\end{abstract}

Keywords: muluki Ain (laws of land), Bhupati (land lords)

\section{BACKGROUND}

'Water': the word is associated with life and soul, and gentleness and quietness. Water is a precious gift of nature. Living things need water in different forms. The Hindu religion represents rivers as feminine entities and water as holy element. Without water, life on earth cannot be sustained. Water is also an inherent component of the ecological chain on which all life and life sustaining systems depend. The whole world is facing a water crisis, and water use has clearly been increasing in recent years, parallel to worldwide economic and scientific development. Populations are growing, and economies and lifestyles are developing, all adding to the stresses on water resources. The world's water crisis is not a crisis of physical water availability but is rather entrenched in an asymmetric power relation, regarding poverty and related inequalities. Furthermore, UNDP Human

Journal of Hydrology and Meteorology, Vol. 6, No. 1
Development Report (2006) notes that if governance fails to address the water crisis, developing countries will not reach the Millennium Development Goals (MDGs) developed by the United Nations in 2000. By addressing water one will also address human development. Lack of access to safe and secure water by people is not due to the quantity of water available on the earth but rather because the institutions set up to manage the water resource are not up to the challenge.

With over $60 \%$ (nearly 5 billion) of the world's population expected to be living in urban areas by 2030 , the issues related to the management of water are being raised to the top of the policy agenda. In Nepal, urban population represents only $14.2 \%$ of the total population. Only $19.5 \%$ of the total population is using piped water, which is normally safe drinking water. Globally and in most countries, agriculture is the largest direct user of

SOHAM-Nepal 
water, accounting for about $70 \%$ of total global withdrawals. Industry, including energy, accounts for another $20 \%$, and it is very unevenly distributed. Domestic water use is typically small in terms of quantities, at most $10 \%$ of the total, but of profound importance in terms of basic human needs, dignity and health. New ways of responding to rapid change and making the urban environment sustainable need to be explored, especially through better management, better service pricing, greater participation of community groups and women, and creative partnerships between public and private sector enterprises. Meeting competing demands from commercial, domestic, and industrial users puts great pressure on fresh water resources. Cities are going ever deeper into groundwater sources and ever farther to more distant surface water resources, at costs that are ultimately unsustainable in both economic and environmental terms. Unless better urban water governance is instituted, the gradation and depletion of freshwater resources will threaten the very livelihood of cities and the sustainability of economic and social development.

\section{HISTORICAL DIMENSIONSS OF WATER RIGHTS IN NEPAL}

When one considers that the changes in conglomeration of rights over land and water in Nepal, three points can be related (Pradhan, 2000). First, developments in land and water rights have not run a parallel course. The Government of Nepal has been relinquishing rights over land, especially arable land, while at same time asserting stronger claims over water. In the classical Hindu theory of kingship, the king was perceived as the owner (swami) of the Earth and the Land Lord (bhupati), and thus the king was the ultimate owner of the land as well as the natural resources on or below the surface of soil (Derrett, 1995). At that time, land could be sold or granted by the King without transferring the right to water or the forest on the land. As Lord of Land, the king had propriety rights not only over land (surface) also over all productive resources within his territory: timber, herbs, wild animals, fish in the waterways, minerals etc. and also trade and crafts carried out in his domain (Burghart, 1996). In the past, the king was only owner of all land in his kingdom, and his subjects had different rights to the land depending on the tenure he bestowed on them.

Over time, the landholding system has developed into a combined system in which private ownership by citizens is a central element, though state ownership has not been abandoned entirely. On the other hand, historically water was hardly regulated. But the water resource has recently been developed through increasing regulation and control and has evolved into a state of full state ownership of all water. Currently, all individual water rights are secondary to the rights to the state. Second, rights over land and water have been dissociated from each other. Though rights to use irrigation water are still linked to land rights, ownership rights over water sources have been delinked from ownership of land. The state owns all water sources (Water Resources Act, 1992), even water sources such as springs on private land. Third, the development and evolution of land and water rights are both part and consequences of broader changes in the political economy. Since the 1970s, water has been increasingly considered as the single-most important natural resource for Nepal's development because of the heavy population pressure on land, dismal agricultural growth, infant industries and service sectors, international alarm about deforestation and the ecological crisis, and international interest in Nepal's water resources. Water is seen as "blue gold", a potential source of enormous revenue for the state and wealth for the elite, especially if hydroelectricity w ere generated and exported to India.

According to Adhikari (1984), the Muluki Ain of 1854 (the "Law of the Land" or the National Code) was part of the wider process of imposing greater and more direct control over the whole kingdom. The Ain contained provisions for land management, revenue administration, land survey, and distribution of land to the landless. It also defined the relations between landlords and peasants. The Muluki Ain 
was based on Hindu religious texts, and it became the foundation for all future legislation. Numerous amendments were made to the Muluki Ain over the years, and finally a new Muluki Ain was promulgated in 1963. The Muluki Ain had numerous provisions concerning land rights, but only a few on water rights, mainly for irrigation. In this Ain, the maker of an irrigation course has prior water rights for irrigation and allocation of water among farmers. The Ain mentioned that first priority should be given to land lying nearer the source.

After the Rana regime ended in 1951, rapid changes occurred in the political economy of Nepal, including activities of the state, massive influx of foreign aid, and enactment of changes in the relative importance of land and water. The growing importance of water was reflected in the promulgation of laws that specially concerned irrigation and water resources, such as the Canal Act of 1961; the Canal, Hydroelectricity and Related Water Sources Act 1967; and the Water Resource Act of 1992. This water related Acts legitimized the state's increasing control and regulation of water, and they vested ownership of water in the state. The Canal, Hydroelectricity and Related Water Sources Act 1967 provided for the allocation and management of water. A part of this Act was the Operation of Irrigation Canal Regulation 1974, which created and gave full authority to the post of irrigation engineer to allocate the water for irrigation, considering the area to be irrigated, cropping patterns, types of soil, and the available quantity of water for irrigation.

There is very little historical evidence about rights in water sources. The rights of the king in the past included the right to tax his subjects for use of water sources and to transfer this right along with the land rights to his subjects to whom he granted or assigned land tenures. There is no evidence of taxes being levied for the use of water source in Kathmandu valley, but a water tax was levied in other parts of Nepal by the Shah Kings in the $18^{\text {th }}$ century and perhaps earlier. Regmi (1978a) mentioned royal orders that reconfirmed rights of local authorities and revenue collectors as well as holder of tenures in the Eastern Terai to levy a variety of taxes on the tenants, including taxes for the use of communal facilities such as forests and sources of water. Pandey (1997) mentioned a tax known as vaulo, which was one of the 36 taxes owed to the kings in Western Nepal between the $14^{\text {th }}$ to the $18^{\text {th }}$ centuries. Vaulo was a tax levied on the subjects for use of ponds or reservoirs which supplied drinking water and in some areas winter irrigation. The vaulo tax was not for use of natural water sources such as rivers, but for constructed water sources and thus perhaps similar to fees currently paid by the irrigators in the state managed irrigation systems.

\subsection{RIGHTS TO WATER AND WATER SOURCES}

There were very few regulations for water before 1951. The pre-1854 regulations were concerned with a) protection of water resources, b) the senior rights of prior appropriators in appropriating water from water sources for irrigation, and c) obligations to repair and maintain irrigation systems. One of the reasons why the Muluki Ain did not regulate water in detail could be that water was not considered an important resource and a source of major revenue. Another reason was that rights to water were included under land rights. Rights to water began to be highlighted only when the state began to be involved heavily in construction and management of irrigation systems and hydroelectricity and when water was considered an important resource. Three versions of the Muluki Ain have provisions about irrigation, and three Acts enacted after 1951 concern irrigation and water resources in general. These provisions deal with three aspects of irrigation:

a) Priority in acquiring water from water sources: The Muluki Ain 1854 is silent about how rights to water sources are established and how they are allocated. The most common local and customary rule was that the right to water from 
an irrigation source was established by constructing a diversion structure. The persons who constructed such diversion structures first to appropriate water for their canals had first priority in diverting water from a common water source. The later versions of the Muluki Ain recognized the customary rules and granted first rights to appropriate water from common water sources to persons who had constructed their irrigation canal earlier. The Muluki Ain 1952 and 1963 prohibited construction of new canals upstream of existing canals if to do so would reduce the water supply to the older canals.

b) Allocation and distribution of water: Water diverted to a canal has to be allocated and distributed to the irrigators. According to Muluki Ain 1854, water is to be allocated and distributed according to customary rules where such rules exist or according to shares if a share system exists. If neither existed, distribution of water was to begin with the field nearest the source of water and move sequentially towards the tail end of the canal. The 1952 and 1963 versions of the Muluki Ain do not mention customary rules or a share system. Those two version added provisions stating that the traditionally irrigated fields should not be deprived of water, but they do not discuss the share of water to be distributed to each irrigation field. The provisions whether riparian rights were to be given priority over rights based on prior appropriation in the sequential order of distribution of water for irrigation especially in situations where the fields of the persons who first constructed canal are located below the newcomers.

c) Obligations to repair canal and security of tenancy: The Muluki Ain 1854 was silent on the obligation of the tenants to repair irrigation systems, but the later two versions instructed the tenants to repair their irrigation systems themselves or provide laborers. If they were unable to repair the canal, they were to inform their local revenue collector.
The various versions of the Muluki Ain did not define who owned the water sources or the types of rights held by different categories of land tenure holders. The water sources were part of the king's possessions (later state domain) rights to which he granted to his subjects along with land and other natural resources. The Acts discussed below were promulgated between 1961 and 1992 reflecting the growing importance of water resources in Nepalese political economy. These Acts not only empowered the state to regulate water use, but they also vested ownership of all water resources in the state.

\subsection{THE CANAL AND OTHER ACTS}

i) Canal Act, 1961: This Act is first legislation described to irrigation, especially irrigation from state-constructed canals. In this Act, the state clearly asserted rights to regulate and control water sources for irrigation purposes, especially for government constructed and managed irrigation systems, and it indirectly claimed ownership rights to water sources. The Act stated that all land lying under naturally flowing or stored water was government land and the Act warns the public not to use these lands without government permission. This Act can be read with the Aquatic Animal Act, 1961, which defines private land as lakes, ponds and natural water storage to which a person has rights and is using and which is on land for which a person pays taxes. The Land Survey and Measurement Act 1963 later included rivers along with roads, forests, and wasteland as government property. The Canal Act 1961 did not define who owned water sources such as rivers; it did recognize limited water rights to be held by the traditional users of water sources from which water was diverted to government irrigation canals. Such persons could claim compensation from the government if the water supply to their fields or traditional water mills from the sources they had been using, was reduced or stopped due to diversion of water to a government canal. The Act deals with rights 
to irrigation water. Irrigators who used government canals had limited rights over the water in canals. They had to use the water for the purpose for which it was sanctioned, and they were not allowed to give it to persons who did not have rights to irrigation from the canal. Rights to irrigation water were tied to specific plots of land within designated command areas (cultivatable land which can be irrigated).

ii) The Canal, Electricity, and Related Water Resource Act, 1967: The Act attempted to control and regulates uses of all water sources, for whatever purpose. The Act considers water to be a very significant resource of Nepal. The Act stated that water resources such as rivers, lakes, and underground water are important aspects of national wealth. The Act required a license for using water sources, except for traditional or non-commercial uses. Thus it was not required for daily personal needs, for operating water mills, or for irrigation using local resources. This Act weakened individual and private rights to water especially in relation to the rights of the state "for the convenience and economic benefit to the general public". Individual and private water rights were secondary to the rights of the state and the public. However, this Act was to be applied only to those water resources which were to be designated by the state by pre-publishing notification in the Nepal gazette.

iii) Water Resource Act 1992: The preamble to the Act states that the Act was promulgated so that water should be utilized rationally and beneficially conserved, developed, managed, and made free from pollution. As owner of all water, the state has the right to regulate who may and may not use water resources, how, where and in which order of priority. It can also expropriate water resources used by the public by paying compensation for all the infrastructures that were created for using the water resources. The expropriation right has a limitation that it can only be done if such expropriation is meant to serve the larger population including the existing population. The Act empowers the state to regulate water use by laying down the order of preference for water utilization. The first preference is given to drinking water and domestic use, followed by irrigation, agricultural uses, including animal husbandry and fisheries, hydroelectricity, industrial use and recreation use. The Act also provides recognition of the Water User's Association (WUA) for collective basis water use. Citizens have rights to use and manage but not to own water sources, and their rights can be terminated at will by the state.

\section{RECENT DEVELOPMENT}

WECS (2002) formulated the first comprehensive Water Resources Strategy of Nepal. A key objective of the Water Resources Strategy is to indentify effective scientific, sustainable and consensus-based mechanism to facilitate the implementation of action-oriented initiatives and programs. The strategy involves the reconciliation of a range of problems and constraints to sustainable water resources development, including those related to government policies, financial and human resources, institutions and actions. The Strategy mentions legal issues of water sector such as nonspecificity of water rights and ownership, lack of sub-ordinate enabling legislation, lack of harmony among related legislation and lack of adequate legal provisions to encourage private sector participation in multipurpose projects. The strategy has made ten outputs with activities and indicators to accomplish purposes of the Water Resources Strategy. Appropriate legal frameworks have proposed on ninth outputs. The legal framework for water use in Nepal must address emerging issues such as water use rights, user conflicts, compensations for reductions in water quality and/ or quantity, and the need for improvement in the enforcement of statutory laws and regulations. In ninth strategic output, activities are formulated as prepare an Integrated Water Resources Policy and amend the Water Resources Act, harmonize and amend conflicting laws and regulations, incorporate 
legislative provision for groundwater use and management, improve the enforcement of acts and regulations, and establish equitable and functional water use rights. In tenth strategic output, the strategy expects appropriate institutional mechanisms for water sector management enhancing planning and implementation capacities of all stakeholder institutions and promote private sector participation. Improving governance will result in better integration of the fragmented government institutions that are responsible for water. It means greater participation by local government, the private sector, civil society, and above all local communities, which should be empowered to have greater control over their local resources.

WECS (1987) has prepared a report titled "An Analytical Survey of the Laws on Water Resources in Nepal." The report reviewed all the existing laws related to water and is an authoritative view of rights to water sources and irrigation. The report argues that the state owns all water resources in the country because of the 1967 Act, which refers to all water sources as national property. The government and individuals, i.e. the general public, have use rights but not ownership rights over water. Private people can use water sources and levy some charges on others for use of facilities if they have rights to improve the water sources, but they can not transfer ownership of the use right because they can not own water resources. Citizens can acquire rights to use water, as stipulated by law, a license issued by the government for all uses of water except for purposes that do not require a license. The provisions of Muluki Ain are not applicable. According to Muluki Ain itself it can only be applicable on matters where there are no separate laws. Since there is a separate legislation on water i.e. the Water Resources Act the provisions of Muluki Ain are not applicable. Section 4 of the Water Resources Act has made certain exceptions to licence and those exception include limited irrigational use such as individual or collective use and other few types uses. Hence one need to understand that the Water Resouces Act has prevailed over the Muluki Ain.

\section{CONCLUSION}

By addressing water, one will also address human development. People's lack of access to safe and secure water is not due to the quantity of water available on the earth but rather because the institutions set up to manage the issues are not up to the challenge. In Nepal, the Muluki Ains (Laws of Land) did not regulate water much in detail because water was not considered an important resource and a source of major revenue. Another reason was that rights to water were included under land rights. Rights to water were highlighted only after the state began to be involved heavily in construction and management of irrigation systems and hydroelectricity and when water began to be considered as an important resource. The growing importance of water was reflected in the promulgation of laws that specially concerned irrigation and water resources. Water rights in Nepal are based on and legitimized by law, and they are related to political, economic, and social relationships and to other rights such as land rights. Changes in political systems and power relationships lead to changes in laws as well as decision making authorities and institutions which in turn affect water rights relationships. Muluki Ain regulates priority in acquiring water from water sources: persons who have first constructed diversion structures on water sources to appropriate water for their canals have first priority in diverting water from common water sources. Regarding allocation and distribution of water, the Muluki Ain stated that water was to be allocated and distributed according to customary rules where such rules existed or according to shares if a share system existed. If neither existed, distribution of water was to begin with the field nearest the source of water and move sequentially towards the tail end of the canal. Acts promulgated between 1961 and 1992 reflect the growing importance of water resources in Nepalese political economy and not only have empowered the state to regulate water use, but also have vested ownership of all water resources in the state. Although various Acts have given equal water rights to every citizen of Nepal, there is still 
gender bias in executing powers and rights to use water sources. Women have user rights in irrigation water and drinking water, but securing and retaining these rights is possible only to those where the other users are related by kinship ties.

Water scarcity problems can perhaps be due to geography, climate change, or the excessive use of water resource in one sector and a resulting loss of raw water available for other uses. Issues needed to be addressed for good water governance are negotiation and collaboration for water sharing, awareness on values of water, managing waterinduced disasters, and the need for wise decisions. Laws and regulations are often useless in confrontations between different water users that need immediate resolution. In these conditions mediation and arbitration by respected intermediaries, preferably with some measure of authority, provide better outcomes than litigation.

\section{REFERENCES}

Adhikari, Krsihan Kant 1984. Nepal under Jang Bahadur, 1846-1877, Vol.1, Kathmandu, Buku

Burghart, Richard., 1996. The conditions of listening. Essays on religion, history, and politics in South Asia, Delhi, Oxford University Press.

CBS, Population Projection 2004. National Planning Commission, $\mathrm{HMG} / \mathrm{N}$.

Derrett, J.D.M., 1995. Essays in Classical and Modern Hindu Law, Vol. 4, Delhi: Universal Book Traders.

Ministry of Population and Environment, ICIMOD, SACEP, NORAD, UNEP, 2001. State of the Environment, Nepal, pp. 121- 132.

Pandey, Ram Niwas., 1997. Making of Modern Nepal, A Study of History, Art and
Culture of the Principalities of Western Nepal, Delhi, Nirala Publications.

Pradhan, R 2000., Land and Water Rights in Nepal (1854-1992), Proceeding of workshop on Changing Rights to Land and Water in Nepal held in Kathmandu, 18-20 March 1998.

UNDP Human Development Report, 2006, http:// hdr.undp.org/.

The United Nations World Water Development Report, 2003. Published by UN World Water Assessment Programme (WWAP), UNESCO, Paris.

WECS, 1987. An analytical survey of the laws on water resources in Nepal, Report No. 4/ 3/19/087/1/1, seqno.272 (Unpublished Report), Kathmandu: WECS.

World Bank, 1992. World Development Report 1992, Development and the Environment, New York, Oxford University Press.

WECS, 2002. Executive Summary of Water Resources Strategy Nepal, prepared by Water and Energy Commission Secretariat, Kathmandu, Nepal. 